\title{
La Fonética articulatoria en el desarrollo de las habilidades orales del idioma Ingles
}

\section{Articulatory Phonetics in the development of English language speaking skills}

Noemi Mercedes Remache Carrillo. ${ }^{1}$, Viviana Vanessa Yanez Valle. ${ }^{2} \&$ María Liliana Cando Carrillo. ${ }^{3}$

Recibido: 12-11-2019 / Revisado: 07-12-2019 /Aceptado: 23-12-2019/ Publicado: 04-01-2020

\begin{abstract}
DOI: $\underline{\text { https://doi.org/10.33262/cienciadigital.v4i1.1093 }}$

Articulatory Phonetics in the development of oral English language skills" is a research project whose main goal was to determine the effectiveness of the use of Articulatory Phonetics in improving English language speaking skills. This descriptive study had a qualitative-quantitative approach which developed a quasi-experimental study. This study had two important groups of students who were active parts of it: the control group had 42 students and the experimental group also had the participation of 42 students. This research was conducted in the classroom therefore had a field research approach; as well as a documentary bibliographic review. The population was made up of students from two parallels of Third Level of English of the Language Center of the Polytechnic School of Chimborazo during the academic period March-July 2019. Additionally, the researchers applied a pre-test and a post-test based on the Cambridge Ket standardized test, which resulted in qualitative data that would then be converted into quantitative data through an evaluation rubric. With this, the Student's T-test was applied to prove or reject the hypothesis. It is concluded that the students improved their skills for oral English language communication through the use of Articulatory Phonetics and it is recommended to address and share this knowledge within the didactic planning to improve the competence of students in their English language skills.
\end{abstract}

${ }^{1}$ Escuela Superior Politécnica de Chimborazo, Riobamba, Ecuador, noemi.carrillo@espoch.edu.ec

2 Escuela Superior Politécnica de Chimborazo, Facultad de Ciencias, Riobamba, Ecuador, viviana.yanez@espoch.edu.ec

3 Escuela Superior Politécnica de Chimborazo, Facultad de Ciencias, Riobamba, Ecuador, marial.cando@espoch.edu.ec 
Keywords: Communication, speaking skills, Articulatory Phonetics, Language, Pronunciation.

\section{Resumen}

La Fonética articulatoria en el desarrollo de las habilidades orales del idioma Ingles es un proyecto investigativo que tuvo como meta principal determinar la efectividad del uso de la Fonética Articulatoria en el mejoramiento de las habilidades orales del Idioma Ingles. Este estudio descriptivo tuvo un enfoque cuali cuantitativo con el cual se desarrolló un estudio cuasiexperimental. Este estudio tuvo dos grupos importantes de estudiantes quienes fueron parte activa del mismo: el grupo de control tuvo 42 estudiantes y el grupo experimental también contó con la participación de 42 estudiantes. Esta investigación se realizó en el aula de clase por lo tanto tuvo un enfoque de investigación de Campo; así como también se realizó una revisión bibliográfica documental. La población estuvo conformada por estudiantes de dos paralelos de Tercer nivel de Inglés del Centro de Idiomas de la Escuela Superior Politécnica de Chimborazo durante el período académico marzo a julio 2019.

Adicionalmente, las investigadoras aplicaron un pretest y un post-test basados en el examen estandarizado Ket de Cambridge con lo cual se obtuvieron datos cualitativos que luego se convertirían en datos cuantitativos a través de una rubrica de evaluación. Con ello, la prueba $\mathrm{T}$ de Student fue aplicada para la comprobación de la hipótesis. Se concluye que los estudiantes mejoraron sus habilidades para la comunicación oral del Idioma Ingles mediante el uso de la Fonética Articulatoria y se recomienda abordar y compartir este conocimiento dentro de la planificación didáctica para mejorar el desenvolvimiento de los estudiantes en sus competencias del idioma Ingles.

Palabras claves: Comunicación, habilidades orales, fonética articulatoria, lenguaje, pronunciación.

\section{Introduction}

In this era of globalization, English is considered as the common language that is used in every place around the world. According to Northrup (2013) English, therefore is the most important language in the world because it is used in business, tourism, technology, science; among other fields (Crystal, 2003). Nevertheless, people who try to learn it is facing some problems especially in their speaking performance.

Wei and Zhou (2002) consider that the low level of English pronunciation break off oral communication among people who come from different cultural backgrounds. In for Phonetics is considered as a difficult theme to learn to achieve oral communication in Asian countries. Chinese university students do not have accuracy when they utter English sounds. Students who are learning English are quiet and shy because of their pronunciation failure (Zhang \& Yin, 2009). 
Ecuadorian students have also problems with English speaking skills. It is mandatory that at the end of the high school they achieve the B1.2 level (Ministerio de Educación de Ecuador, 2017). Taking into consideration the fact that, written and oral English are two completely distinct matters (O'Connor, 2009); Ecuadorian students are failing in written and oral productions. Olivo (2016) states that there is a confusion between English and Spanish sounds because students pronounce sounds with their mother tongue influence. Furthermore, students remark that speaking skills are very difficult to learn as well as teachers have the same feelings with respect to pronunciation (Gonzalez, et al., 2015). For that reason, the students come to the higher education with serious speaking skills deficiencies.

At Languages Center of Escuela Superior Polytechnical de Chimborazo, according to teacher's grading registers taken from the diagnostic test, English speaking skills have a remarkable difficulty. Students do not have a proper way of pronunciation because they produce both Spanish and English sounds in the same way. Further, they are afraid at the moment of performing a speaking practice in class; and, they do not want to develop oral productions or interactions.

Accordingly, this study is focused on two main variables: the dependent variable is named as English speaking skills development and the independent one is called as Articulatory Phonetics; both of them are linked to improve students' oral English competence; that is the reason why the present research was interesting, helpful, and feasible.

This study was interesting because Articulatory phonetics for English speaking skills development is helpful for a better teaching practice thereby having a good knowledge about phonetic symbols individuals can upgrade their pronunciation. Authors of the dictionaries write phonetic transcriptions next to the words, and students do not know how to read or use them; therefore, it becomes significant to learn about those signs (Garcia, 2012) for a better understanding and use of English language. Besides, most of the electronic dictionaries have audios with the pronunciation and the phonetic transcription; consequently, it is good that students have a general idea of what they mean (Fernandez, 2016). Furthermore, students learn to pronounce words and sentences with the appropriate stress and intonation which means that their communication is understandable and competent.

Moreover, the present research was helpful. According to Salazar (2013) having a good level of English-speaking skills is useful. It means that, when people produce sounds of speech appropriately, they can be understood by others even if they do not come from the same culture or country. A good speaking skills development avoids misunderstanding since it is valuable in oral interaction and production (Council of Europe, 1991).

Additionally, this research was feasible because students and researchers had the opportunity to work with and apply Articulatory phonetics topics for improving students' speaking skills 
development. Furthermore, there was the students' and researchers' commitment to accomplish the proponed goal.

\section{Phonetics}

Shaghi (2015) states Phonetics is the sounds of speech depiction in any language. It portrays how vowels and consonants are produced and listened and what acoustic features they have. Furthermore, Firth (2008) states that it is the part of Linguistics that deals with the sounds of speech. Phonetics is the art which studies practical data about pronouncing and perceiving the sounds of speech that are used for communication purposes. Therefore, phonetics aims to provide an objective description of speech. Furthermore, this linguistics branch uses the International Phonetic Alphabet. The International Phonetic Association created it. The IPA contains standard symbols, according to Laver (1994), that are used in phonetic transcriptions.

Phonetics is sub-divided in terms of description of the sounds of speech. Therefore, they are: Acoustic Phonetics, Auditory Phonetics, and Articulatory phonetics. Sounds of speech are studied in various modes depending on their approach of research and their properties (Herbst, 2010)

\section{Articulatory Phonetics}

It is the subfield of Phonetics which deals with the exact movements that are needed for the uttering of the sounds of speech. For example, the sound / $\theta$ / as in 'thin' has three different classifications; hence, it is fricative because the air stream is pushed out with much friction; interdental for the interaction between the edge of the upper teeth with the tip of the tongue, and voiceless due to this sound is produced without vocal chords vibration (László, 2014).

Articulatory Phonetics studies the way how speech sounds are done or articulated. Brinton and Brinton (2010) emphasize that Articulatory phonetics manages the physiological mechanisms of speech production by human being issues. Zhu (2015) considers that the sounds of speech are produced by the organs of speech and the vocal folds establish the amount of the flow of air that is needed when it passes through them for sounds production.

\section{Sounds of speech}

Human beings are capable of producing a number of sounds; however, not all of them are used for communication; for example, a dental click is not recognized as a speech sound. On the contrary, those sounds that are used for communication are called speech sounds; for instance, /b/ is recognizable as a sound of speech because it is found in words like 'bin', 'banana', 'laboratory', 'cab', and many others. Therefore, a sound of speech is that appears in words of certain language (Williamson, 2015).

It was compared the sounds of speech like unformed and unburnt clay that serve to model bricks which represent the language elements (Sapir, 1921). Yule (2010) states that those sounds are classified in vowels and consonants which are also classed as Phones. Celce-Murcia, Brinton, and 
Goodwin (1996) argue that vowels and consonants are represented in the International Phonetic Alphabet.

\section{Vowels}

Vowels are sounds of speech which are produced by human beings when the airstream flows out through the vocal cavity without being blocked by teeth, lips, or tongue. There are two kinds of vowels: 1) short vowels are short sounds such as the pronounced in the word 'cup'; on the other hand, 2) long vowels are long sounds as in 'shoe' (Cambridge Dictionary, 2018).

Five out of 26 letters of the alphabet are vowels that are sounds which are produced in the vocal cavity by the flow of air that comes from the lungs without closing any part of the throat and mouth. Letter Y is considered both as a vowel and consonant because when it starts a word like in 'yellow' it is considered as a consonant; unless, it ends a word like in 'sunny' or 'baby' it is considered as a vowel. Vowels can be studied as they are monophthongs, which are pronounced at once, and diphthongs that changes character during their uttering (Shaghi, 2015).

\section{Consonants}

21 out of 26 letters of the English alphabet are consonants. While vowels are produced by letting the airflow passes through the vocal cavity without any obstruction, consonants are produced by blocking the airstream with the teeth, tongue, lips, or palate; for instance, the sound $/ \mathrm{b} /$ is produced when the lips block the airstream, and the letter /1/ is pronounced when the tongue touches the palate. English consonants are produced when the vocal tract narrows; it also depends whether the vocal cords vibrate or not, and if the flow of air passes through the nose or not (Shaghi, 2015)

\section{Places of Articulation}

Based upon Yule (2010) the consonants are classified by their place of articulation in the oral cavity as: bilabial, labiodental, Dentals and Interdentals, Alveolar, Post-alveolar, Palatals, Velars, and Glottal.

Bilabial sounds like $/ \mathrm{m} /, / \mathrm{p} /$, and $/ \mathrm{b} /$ are produced when the upper and lower lips are joined together (Yule, 2010). To produce these sounds, the mouth is completely closed (O'Connor, 2009); in this way the airstream is stopped for a split second and an explosion is followed as in /my/, /put/, /but/ (Herbst, 2015). Labiodental sounds are produced when the lower lip and the upper teeth joined together (Herbst. 2015). The airstream flows through these two organs of speech. This action produces the following sounds: /f/, /v/. /f/ is a voiceless sound and /v/ is a voiced sound (Yule, 2010). Dentals and Interdentals are produced when the tongue tip is placed behind the upper front teeth to produce the sounds $/ \theta /$ as in /thought/ and /ð/ like in /that/ (Herbst, 2015). /ठ/ is a voiced sound; however, $/ \theta /$ is voiceless. Furthermore, Interdentals are produced between the upper and lower teeth by the tongue tip (Yule, 2010). 
Moreover, alveolar sounds are uttered in the front part of the tongue on the alveolar ridge touches behind and above the upper teeth to produce the following sounds: /t/, /d/, /s/, /z/, and /n/. Other alveolar sounds are the initial sounds like in "lab" and "rose" and the phonetic transcriptions are $/ \mathrm{l} /$ and $/ \mathrm{r} /$. Notice that $/ \mathrm{t} /$ and $/ \mathrm{s} /$ are voiceless sounds while $/ \mathrm{t} /, / \mathrm{d} /$, and $/ \mathrm{s} /$ are voiced sounds (Yule, 2010). In other words, the tongue tip contacts with the alveolar ridge or is in close approximation of it (Brinton \& Brinton, 2010). Post- Alveolar sounds are uttered when the tip, rims, and blade of the tongue are in contact with the rear part of the upper alveolar ridge (Herbst, 2015). Palatals or alveo-palatals are produced when the front of the tongue is in contact with the palate (Brinton $\&$ Brinton, 2010). Initial sounds of /should/ and /child/ are examples of palatals. Those sounds are voiceless. Sound /ch/ is phonologically represented as / $\mathfrak{t} /$ like in 'church' $/ \mathfrak{t} 3: \mathfrak{t} /$. Sound /sh/ is represented as / $/$ / like in "should" / $v 0 \mathrm{~d} /$. Moreover, the sound /dz/ which can be found in the initial and final sound of /judge/ is a voiced palatal; as well as the voiced sound/3/ which appears in the middle of the word /measure/. Furthermore, there is another voiced palatal which is used in the initial sound of /yes/ and is represented by /j/ phonetic symbol (Yule, 2010). Velar sounds are produced when the back part of the tongue is brought up against the velum (Brinton \& Brinton, 2010). Those sounds are: / $/ \mathrm{k}$ as in cold, /g/ as in "go" and the nasal sound/y/like in "sing". Notice that $/ \mathrm{k} /$ is a voiceless sound and $/ \mathrm{g} /$ is a voiced sound (Yule, 2010).Glottal sounds as the initial sound of "house" /h/ and sometimes speakers utter as the same initial sound in "who" and "whose" is called Glottal. This sound is produced without any active part of the tongue or other parts of the mouth. It is just produced in the throat when the glottis is open. Glottal sound is voiceless (Yule, 2010). In this case vocal cords work as articulators and make a slight closure (Brinton \& Brinton, 2010).

\section{Manners of articulation}

On the other hand, Yule (2010) explains that the consonants are produced in different manners such as Stops, Fricatives, Affricates, Nasals, Liquids, Glides, and Glottal Stops and flaps.

Consonants which are the result of a complete blocking or obstruction of the air stream at some point in the mouth (O'Connor, 2009) with the velum raised (Brinton \& Brinton, 2010) for a very short time and then let it go suddenly (Herbst, 2015) are called "stops" or "plosives". Sounds that produce certain form of stopping are: /p/, /b/, /t/, /d/, /k/, and /g/ (Yule, 2010). Further, fricatives are sounds of speech which are produced when the organs of the vocal cavity have narrow opening and the air stream is pushed out. $/ \mathrm{h} /, / \mathrm{f} /, / \mathrm{v} /, / \theta /, / \mathrm{d} /, / \mathrm{s} /, / \mathrm{z} /, / \mathrm{J} /$, and $/ \mathrm{z} /$ are called as Fricatives (Yule, 2010). Their main characteristic is that all of them have friction (O'Connor, 2009). Affricates are sounds of speech that are formed when the flow of air is stopped somewhere in the vocal cavity and then it is pushed out slowly forming a friction (Herbst, English Linguistics: A Coursebook for students of English, 2015). Affricates are: /d্ / and / t / as in "cheap" and "jeep" (Yule, 2010). 
Sounds of speech are called Nasals when the air stream is stopped in the oral cavity and is passed through the nose (Herbst, 2015). Nasals are: $/ \mathrm{m} /, / \mathrm{n} /$, and $/ \mathrm{y} /$. They all are voiced sounds like in "morning", "knitting", and "name" (Yule, 2010). The sounds of speech /r/ and /1/ are described as liquids (Yule, 2010) or laterals. These consonants are voiced sounds. Liquids are produced because the speaker approximates his tongue to a place of articulation in the vocal cavity however it is not close enough to produce any stop of the air flow (Herbst, 2015). Furthermore, /j/ and /w/ are Glides. These consonants are also called semivowels. These consonants are voiced and are found at the beginning of "yes" and "we" respectively. They are produced through a smooth continuous movement of the tongue (Yule, 2010). They are also called as "approximants" because the tongue is contracted and the mainstream of the air can be released without friction (Herbst, 2015).

Table 1. English consonants. Manners and Places of Articulation

\begin{tabular}{|c|c|c|c|c|c|c|c|c|}
\hline \multicolumn{2}{|c|}{$\begin{array}{l}\text { Point } \rightarrow \\
\text { Manner } \\
\downarrow\end{array}$} & Bilabial & $\begin{array}{l}\text { Labio } \\
\text { Dental }\end{array}$ & $\begin{array}{l}\text { Dental or } \\
\text { interdental }\end{array}$ & Alveolar & $\begin{array}{l}\text { Post- } \\
\text { Alveolar } \\
\text { (palatal or } \\
\text { palato- } \\
\text { alveolar) }\end{array}$ & $\overline{\text { Velar }}$ & $\overline{\text { Glottal }}$ \\
\hline \multicolumn{2}{|c|}{ Plosive or stop } & $\mathrm{p} \underline{\mathrm{b}}$ & & & $\mathrm{t} \underline{\mathrm{d}}$ & & $\mathrm{kg}$ & \\
\hline \multicolumn{2}{|c|}{ Affricate } & & & & & $\mathrm{t} \int \underline{\mathrm{d} z}$ & & \\
\hline \multicolumn{2}{|c|}{ Fricative } & & $f \underline{v}$ & $\underline{\partial} \theta$ & $\mathrm{s} \underline{z}$ & 35 & & h \\
\hline \multicolumn{2}{|c|}{ Nasal-stop } & $\underline{\mathrm{m}}$ & & & $\underline{\mathrm{n}}$ & & n & \\
\hline \multicolumn{2}{|c|}{ Semi-Vowels } & $\underline{w}$ & & & & i & (w) & \\
\hline \multirow[b]{2}{*}{ 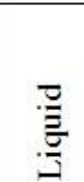 } & Lateral & & & & $\underline{1}$ & & & \\
\hline & $\begin{array}{l}\text { Approxima } \\
\text { nt }\end{array}$ & & & & $\underline{\underline{r}}$ & & & \\
\hline
\end{tabular}

Source: Learning English (2018)

\section{Methodology}

The present study applied a quasi-experimental design which main goal is to determine whether the use of Articulatory Phonetics enhances English language speaking skills development of students belonging to Third level of English at Language Center of Escuela Superior Polytechnical de Chimborazo for the March - July 2019 academic period.

This research was also centered on quail quantitative approach because most of the work was theoretically based. This theoretical data was transformed into numbers for the data analysis and for proving the hypothesis (Marzano, Vegliante, \& De Angelis, 2015). In addition, this work was based on the Social Educational Model for education which is part of life. Besides, English language is used for communication purposes because it is considered a global language (Crystal, 2003). Finally, acquired data have been ascertained with T Student test Mathematics Model. 
Besides, this descriptive investigation; in measured and described a series of actions which took place in the field of research (Hernández, Fernández, \& Baptista, 1997). Moreover, this documentary study used primary and secondary bibliographical materials because the researcher assessed and analyzed bibliographical data. Applied and field research were also used because they aim to solve problems of daily life (Cherry, 2017). Therefore, this research proposed a teacher's intervention for enhancing students' English-speaking skills. Besides, it was field research because classes were useful for the researcher to determine and conceptualize the research problem to be solved with students of the experimental group.

As it was a quasi-experimental research, two groups of students were chosen to be active part of it (Kowalczyk, 2003). Both the control and the experimental group took the pre-and post-tests (Cohen, Manion, \& Morrison, 2007). Finally, the researcher applied the T Student Mathematical test to perform the data analysis and interpretation of means results (Frost, 2016).

This research was conducted with the population showed in the table 4 which is detailed below.

Table 2. Population

\begin{tabular}{llllll}
\hline CLASS & ROOM & MEN & WOMEN & TOTAL & GROUPS \\
\hline $\mathbf{3}$ & M & 25 & 17 & 42 & $\begin{array}{l}\text { Experimental } \\
\text { Group }\end{array}$ \\
$\mathbf{3}$ & $\mathrm{S}$ & 23 & 19 & 42 & Control group \\
TOTAL & & 48 & 36 & 84 & \\
\hline
\end{tabular}

Source: Field Research

Created by: Remache, N. (2019)

\section{Analysis and interpretation}

For analyzing the pre-test and post-test of the experimental group; students' dialogues and oral performance were developed. Four speaking skills categories were assessed. Besides, a rubric was designed according to those four criteria such as pronunciation of vowels, production of consonants, stress, and intonation. The instrument was the speaking part of the KET Exam (KET Speaking, 2016) which includes personal information questions. This questionnaire was also based on the CEFR (Council of Europe, 1991). For data interpretation, the researcher took into account the obtained results from the rubric. Seven questions where applied and students had to answer them in a pair interview. The teacher took notes and assigned grades according to the whole content of the interview. Hence, pronunciation of vowels, pronunciation of consonants, stress, and intonation were determined in different numbers, the researcher gave the students individual scores according to the rubric and their speaking skills development. 


\section{Speaking skills performance. Control group}

Table 3. Speaking skills. Pre and Post-tests results

\begin{tabular}{lcc}
\hline \multicolumn{3}{c}{ CONTROL GROUP } \\
\hline & $\begin{array}{l}\text { Data before the } \\
\text { treatment }\end{array}$ & $\begin{array}{l}\text { Data } \\
\text { treatment }\end{array}$ \\
\hline Vowels & 1.26 & 1.57 \\
Consonants & 1.26 & 1.55 \\
Stress & 1.29 & 1.48 \\
Intonation & 1.21 & 1.45 \\
Expected Average & 4.00 & 4.00 \\
\hline
\end{tabular}

Created by: Remache, N. (2019)

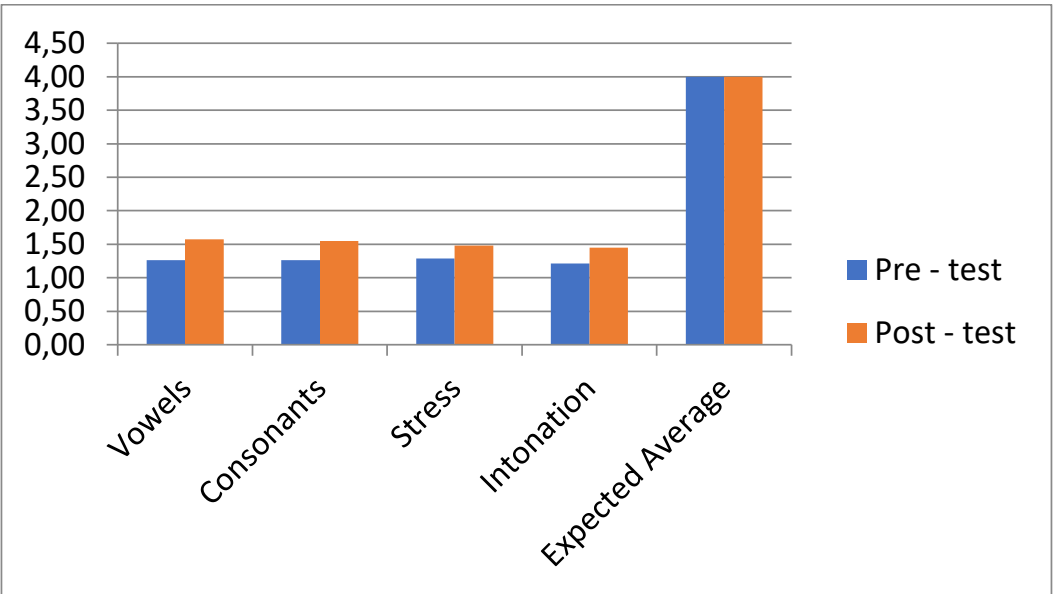

Figure 1. Pre and post-tests results

Created by: Remache, N. (2019)

The pre and post-tests results in the control group had a slight difference between the pre and posttests because in the pre-test the result was 1,26 and in the post-test the result was 1,57. In the same way, a slight difference exists between the results of the pronunciation of consonants being 1,26 in the pre-test and 1,55 in the post-test. Similarly, stress did not evidence any advancement with the control group hence the result in the pre-test was 1,29 and in the post-test was 1,48. Finally, Intonation results did not improve either; so, at the beginning the score was 1,21 and after the treatment, the result was 1,45 .

To sum up, the English-speaking skills of the students who belonged to the control group did not improve. 


\section{Pre - Post-test experimental group}

Table 4. Speaking skills Pre and Post-tests results

\begin{tabular}{lcl}
\hline \multicolumn{3}{c}{ EXPERIMENTAL GROUP } \\
\hline Criteria & Pre - test & Post - test \\
Vowels & 1.23 & 2.82 \\
Consonants & 1.28 & 2.79 \\
Stress & 1.23 & 2.92 \\
Intonation & 1.25 & 2.97 \\
Expected Average & 4.00 & 4.00 \\
\hline
\end{tabular}

Created by: Remache, N. (2019

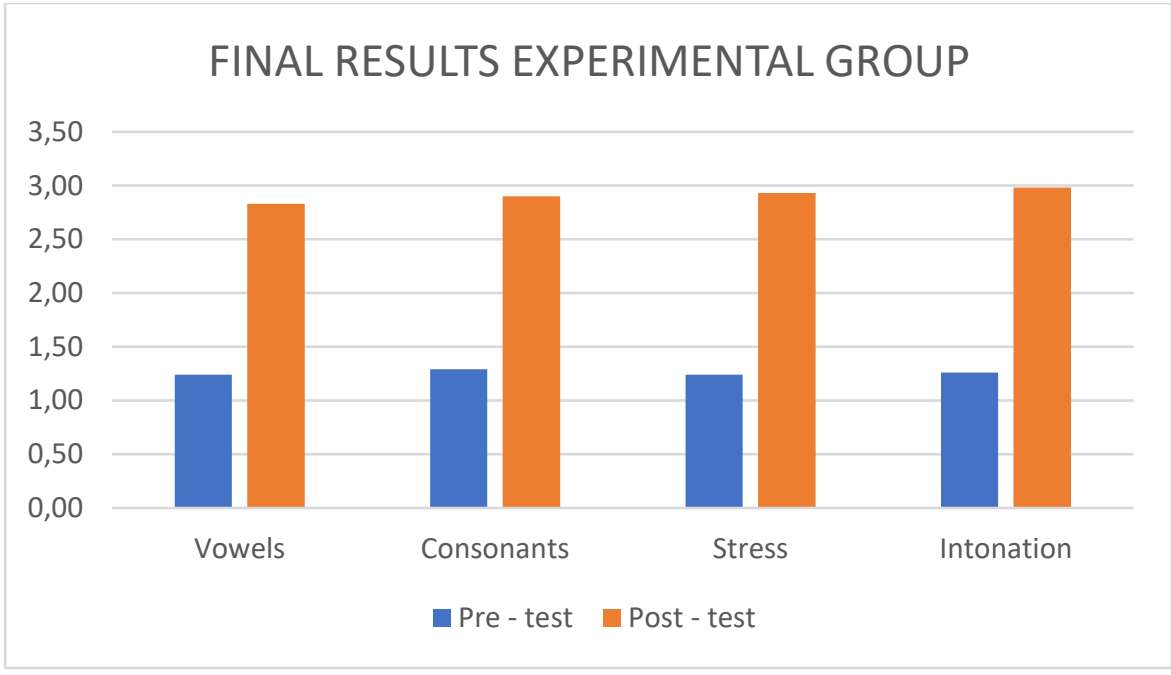

Figure 2. Speaking skills Categories. Pre and post-tests results Created by: Remache, N. (2019)

The table above shows that the population have notably enhanced their English-speaking skills. Hence, they showed an improvement in their score from 1,23 to 2,82 related to the vowels uttering. At the same time, their production of consonant sounds has also increased from 1,28 to 2,79. Besides, the experimental group showed an important improvement in stress from 1,23 in the pretest to 2,92 in the post-test. Finally, in intonation, they also improved from 1,25 to 2,97.

Thanks to an important intervention that included Articulatory phonetics topics for the English language learning, the results mentioned above clearly depict the students' improvement. 


\section{Comparison Experimental and Control Groups}

Table 5. Comparison Experimental Group and Control Group

\begin{tabular}{lllll}
\hline & \multicolumn{2}{l}{} & \multicolumn{2}{l}{$\begin{array}{l}\text { EXPERIMENTAL } \\
\text { GONOUP }\end{array}$} \\
\cline { 2 - 5 } & Pre - test & Post - test & Pre - test & Post - test \\
\hline Vowels & 1.26 & 1.57 & 1.23 & 2.82 \\
Consonants & 1.26 & 1.55 & 1.28 & 2.79 \\
Stress & 1.29 & 1.48 & 1.23 & 2.92 \\
Intonation & 1.21 & 1.45 & 1.25 & 2.97 \\
\hline
\end{tabular}

Created by: Remache, N. (2019)

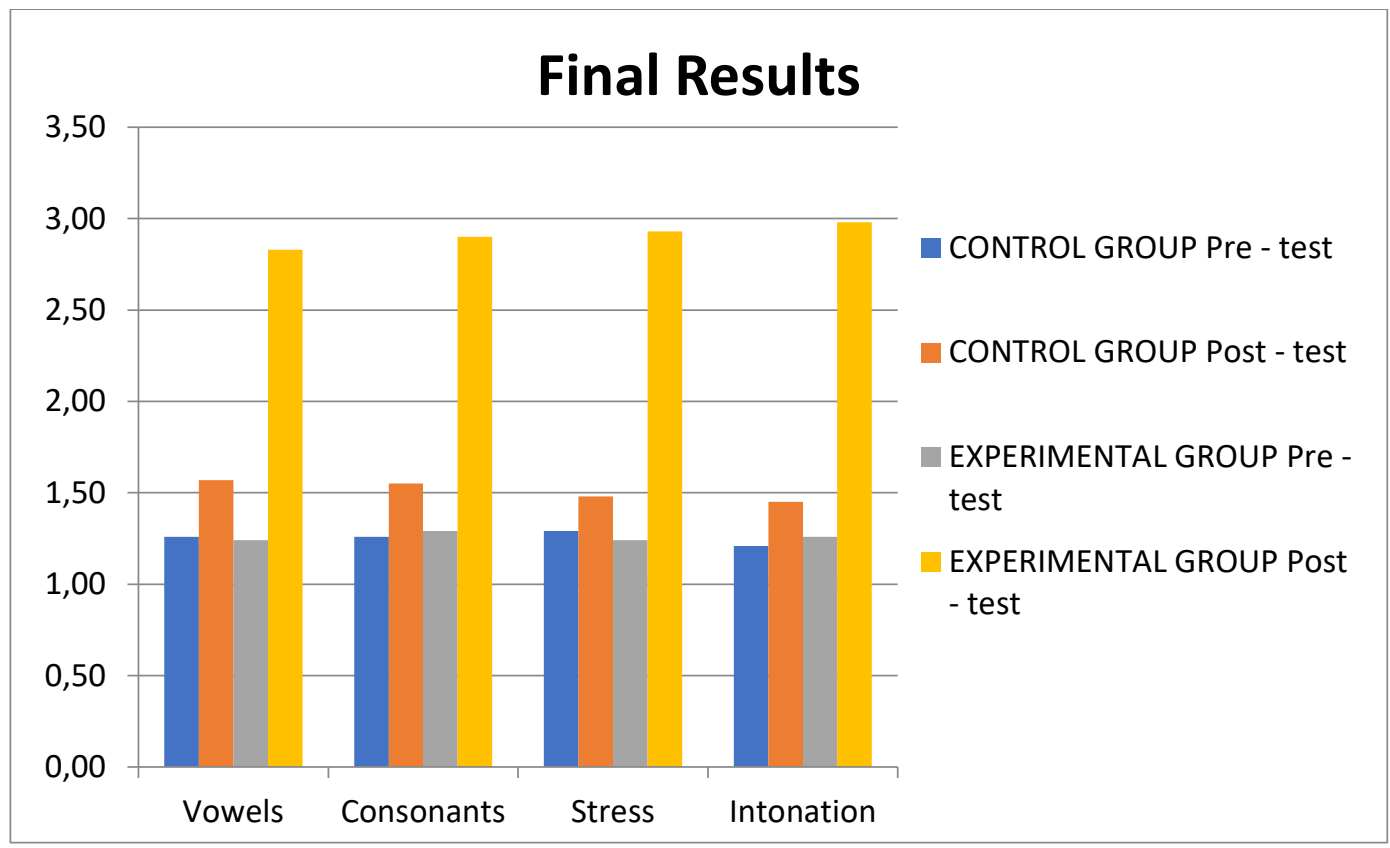

Figure 3. Comparison Experimental and Control Group

Author: Remache, N. (2019)

In the comparison between the obtained results of the Experimental group as well as the Control group of students.

These results evidence that the experimental group had an improvement in the English-speaking skills pronunciation development because Articulatory phonetics was studied while the Control group of students had English classes but they did not study Articulatory phonetics topics.

4.3. Hypothesis verification 


\section{Normality test}

For the Normality test, the Kolmogorov-Smirnov was applied.

Table 6. Group Statistic

One-Sample Kolmogorov-Smirnov Test ${ }^{\mathrm{a}}$

\begin{tabular}{lll}
\hline & & $\begin{array}{l}\text { Pre- } \\
\text { test }\end{array}$ \\
\hline $\mathrm{N}$ & Mean & 42 \\
Normal Parameters $^{\text {b,c }}$ & Std. Deviation & 5.02 \\
& Absolute & .412 \\
Most Extreme Differences & Positive & .412 \\
& Negative & -.279 \\
Test Statistic & & .412 \\
Asymp. Sig. (2-tailed) & & $.000^{\mathrm{d}}$ \\
\hline
\end{tabular}

Source: Field Research

Created by: Remache, N (2019)

The means difference of the control group between the pre and post-test is 0.000 . This p.sig is lower than 0.05 which means that the data obtained for this research as asymmetric.

\section{T-test}

Table 7 . T-test

Paired Samples Statistics

\begin{tabular}{|c|c|c|c|c|c|}
\hline & & Mean & $\mathrm{N}$ & $\begin{array}{l}\text { Std. De- } \\
\text { viation }\end{array}$ & $\begin{array}{c}\text { Std. Er- } \\
\text { ror } \\
\text { Mean }\end{array}$ \\
\hline \multirow{2}{*}{ Pair 1} & Control group Pre-test & 5.02 & 42 & 1.746 & .269 \\
\hline & Control group Post-test & 6.05 & 42 & 2.845 & .439 \\
\hline \multirow{2}{*}{ Pair 2} & $\begin{array}{l}\text { Experimental group Pre- } \\
\text { test }\end{array}$ & 5.02 & 42 & 1.787 & .276 \\
\hline & $\begin{array}{l}\text { Experimental group Post- } \\
\text { test }\end{array}$ & 11.64 & 42 & 2.526 & .390 \\
\hline
\end{tabular}

Created by: Remache, N (2019) 
With a confidence level of 0.95 or $0.95 \%$, it is showed that the means from the control group were 5.02 in the pre-test and 6.05 in the post test with 42 valid cases. It refers that, there is a slight improvement in the means for the control group who did not receive specific classes using Articulatory phonetics. On the contrary, the averages of the experimental group were 5.02 in the pre-test and 11.64 in the post test. Therefore, there is a big difference in the means of the pretest and the posttest.

So, it is concluded that there is a high difference between the means of the control group and the means of the experimental group. So, Articulatory phonetics use enhanced English-speaking skills development.

\section{Conclusions}

- It was determined that Articulatory Phonetics application improved English speaking skills development to third level students. This result was obtained during the whole process, before the intervention and after the intervention. Based on the diagnostic test, the researchers figured out that students have deficiencies in their speaking skills, that was the reason why they implemented a treatment using Articulatory phonetics in order to help them to enhance their speaking skills with successful results.

- A theoretical review was performed which included the sounds of speech with their production and kinds according to their points of articulation and manners of articulation. This information shared and greatly explained by the researchers in the process was useful for the students to increase their knowledge of English language. This information was crucial because students learned how to produce English sounds and were aware of their differences between their mother tongue and English.

- Data obtained before and after the researcher's intervention in the class were analyzed and interpreted. Data gave the opportunity to diagnose the students' English-speaking skills level at the beginning. Based on these results, class planning which included special pronunciation features was developed. These data informed about the successful results of the intervention using Articulatory phonetics.

\section{Referencias bibliográficas}

Bigham, D. (2014). Lexicon Valley. from How Many Vowels Are There in English?: (Hint: It's More Than AEIOUY.) : https://slate.com/human-interest/2014/08/

Cambridge Dictionary. (2018). Cambridge Dictionary. Retrieved 2018, from https://dictionary.cambridge.org/es/diccionario/ingles/vowel 
Fernández, D. (2016). La Fonética y sus símbolos. Retrieved from https://blog.aprendingidiomas.com/author/david/

Gonzalez, P., Ochoa, C., Cabrera, P., Castillo, L., Quiñonez, A., Solano, L., . . arias, M. (2015). EFL Teaching in the Amazon Region of Ecuador: A Focus on Activities and Resources for Teaching Listening and Speaking Skills. Retrieved from: http://files.eric.ed.gov/fulltext/EJ1075454.pdf

László, S. (2014). Put English Phonetics into Practice. Retrieved from http://geniusja.uz.ua/sites/default/files/csatolmanyok/magyar-nyelvu-oktatasi-jegyzetek-es-magyarnyelvu-szaknyelvi-szotarak-keszitese-a-nyertesek-dokumentumai-725/bookenglishphonetics.pdf

Ministerio de Educación de Ecuador. (2017). Fortalecimiento del Ingles: Retrieved from https://educacion.gob.ec/fortalecimiento-del-ingles-prin/

Zhu, X. (2015). Phonetics Articulatory. Retrieved from https://www.academia.edu/12187319/PHONETICS_ARTICULATORY

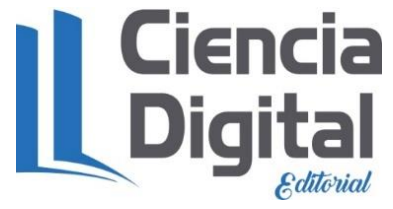




\section{PARA CITAR EL ARTÍCULO INDEXADO.}

Remache Carrillo, N. M., Yanez Valle, V. V., \& Cando Carrillo, M. L. (2020). La Fonética articulatoria en el desarrollo de las habilidades orales del idioma Ingles. Ciencia Digital, 4(1), 182196. https://doi.org/10.33262/cienciadigital.v4i1.1093

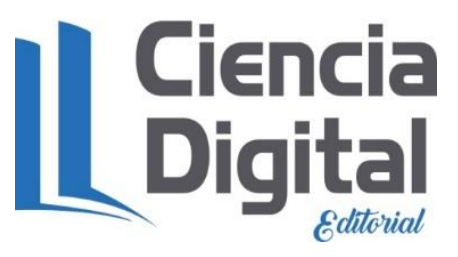

El artículo que se publica es de exclusiva responsabilidad de los autores y no necesariamente reflejan el pensamiento de la Revista Ciencia Digital.

El artículo queda en propiedad de la revista y, por tanto, su publicación parcial y/o total en otro medio tiene que ser autorizado por el director de la Revista Ciencia Digital.
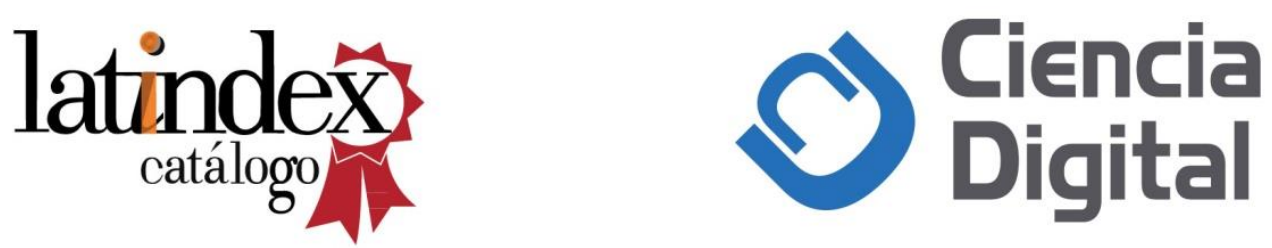